\title{
Assessment of Indoor Microbial Quality of Library's Premise: Case of Central Library of the University of Yaoundé I
}

\author{
Kengne Gounmadje Landry ${ }^{1}$, Nyegue Maximillienne Ascension'²* \\ Djuidje Chatue Ide Armelle ${ }^{2}$, Gonsu Kamga Hortense ${ }^{3}$, Etoa François-Xavier ${ }^{2}$ \\ ${ }^{1}$ Department of Biochemistry, University of Yaoundé I, Yaoundé, Cameroon \\ ${ }^{2}$ Department of Microbiology, University of Yaoundé I, Yaoundé, Cameroon \\ ${ }^{3}$ Laboratory of Bacteriology, CHU, Yaoundé, Cameroon \\ Email: *maxy_nyegue@yahoo.fr
}

How to cite this paper: Landry, K.G., Ascension, N.M., Armelle, D.C.I., Hortense, G.K. and François-Xavier, E. (2018) Assessment of Indoor Microbial Quality of Library's Premise: Case of Central Library of the University of Yaoundé I. Open Journal of Preventive Medicine, 8, 109-120.

https://doi.org/10.4236/ojpm.2018.84011

Received: February 12, 2018

Accepted: April 22, 2018

Published: April 25, 2018

Copyright $\odot 2018$ by authors and Scientific Research Publishing Inc. This work is licensed under the Creative Commons Attribution International License (CC BY 4.0).

http://creativecommons.org/licenses/by/4.0/

\begin{abstract}
Background: Good indoor air quality is important for human health and comfort, because people spend a most of their time within buildings. Microbial pollution is a key element of indoor air pollution. Bacteria and fungi growing indoors when sufficient moisture is available usually cause indoor air pollution. Methods: This study was conducted to assess the microbial concentration and to identify the main bacteria and fungi in the indoor environment of Central Library of the University of Yaoundé I. A total of 76 samples were taken from indoor air, surfaces and mouldy books. Bioaerosol sampling and air concentration were made by passive air sampling technique using petri dishes containing different culture media and exposed for 30,60 and $90 \mathrm{~min}$ in the morning and afternoon. Sampling of surfaces and mouldy books were made by rubbing using sterile swab. The identification of the isolated microorganisms was based on macroscopic, microscopic and biochemical characters. Results: The concentrations of bacteria and fungi in the indoor environment of Central Library of the University of Yaoundé I ranged between 747 and $2324 \mathrm{CFU} / \mathrm{m}$ for the air and 40 and $500 \mathrm{CFU} / \mathrm{cm}^{2}$ for surfaces. In the examined area, the predominant culturable species of microflora were members of the following bacteria genera; Bacillus spp, Staphylococcus spp, Micrococcus spp, Pseudomonas spp, Rhodococcus spp, Enterobacter spp, Klebsiella spp and Escherichia spp and fungi; Aspergillus spp, Penicillium spp, Curvularia spp, Mucor spp, Cladosporium spp, Candida spp Rhodotorula spp, Fusarium spp, Trichophyton spp, Acremonium spp, Aureobasidium spp, Rhizopus spp and Chrysonilia spp. Conclusion: High concentrations of bacteria and fungi were observed in the central library of the University of
\end{abstract}


Yaoundé I. Precautions and safety measures should be taken to reduce microbial pollution at universities libraries by improving libraries ventilation and disinfection.

\section{Keywords}

Microbial Pollution, Library, Identification, Fungi, Bacteria

\section{Introduction}

Confined workplaces such as offices, hospital wards and conservation buildings are so far involved in indoor pollution problems [1]. This calls for special attention as modern man spends $90 \%$ of his time inside confined spaces, $50 \%$ in dwellings and $30 \%$ in workplaces [2]. In addition, many studies show that the air inside houses and buildings is highly polluted whether in an industrial environment or not [3]. Many confined spaces are fully or partially closed releasing odour that reflects a poorly ventilated place, with a high relative humidity, giving rise to an abundant microbial proliferation [4]. The presence of fungal spores in indoor environments is till date a major public health concern and economic importance [1]. The World Health Organization has declared that 4.3 million premature deaths are related to indoor air pollution [5]. For many sectors of activity, fungal and bacterial spores are responsible for infections such as food poisoning and nosocomial infections in the food and hospital sectors respectively [1].

In addition to the food and hospital sectors, contamination of library collections and premises is also of great interest. In fact, mould is one of the problems of collections, buildings and historical objects, whether aesthetically or structurally intact [6]. In addition, bacterial endotoxins and mycotoxins are risk factors for the human health especially for people who handle contaminated structures as well as those working on these premises. Libraries must therefore, as an institution that is open to the public, respect the rules of hygiene and sanitation designed to preserve the health of its occupants, particularly; circulation of air, protection against humidity and temperature variations. For this purpose, since 2011, the WHO requires institutions receiving public (ERP) to monitoring air quality according to Article L221-8 of the Environmental Code. Previously, the Grenelle law of July 2, 2010 recommends periodic microbiological controls, installation and maintenance of climate control and ventilation systems to limit unplanned microbial contamination. However, not all libraries have the financial means to install a ventilation and climate control system to limit microbial contamination and development. The Central Library of the University of Yaoundé I (CL-UYI) is no exception, given its low acquisition budget [7]. In tropical climates, the absence of these climatic control systems leads to a periodic reappearance of moulds in libraries [8]. 
Given these observations, it is questionable whether the CL-UYI does not represent a site posing a threat to the health of its occupants. It is in order to answer this question that the present study was carried out in order to have a wider knowledge of pathogenic microorganisms present on the premises of the CL-UYI, which will make it possible to estimate and prevent the health risk linked to the exposure of users to microorganisms and improve the conditions of collections conservation.

\section{Methods}

\subsection{Study Area}

The Central Library of the University of Yaoundé I is an educational building established in July 1999. It is located inside the University campus of Yaoundé I. Its area is $5800 \mathrm{~m}^{2}$ and it has a capacity of 1000 seats and employs 28 permanent staff. The opening hours vary from 9:00 a.m. to 10:00 p.m. depending on the days of the week (Monday Saturday). This building receives on average 1500 students per day. In its structure, the CL-UYI has 02 levels, a basement and a ground floor. We chose CL-UYI as a place of study for a number of reasons. Firstly, because this library is frequented by many students and other users. Secondly, the library, like any confined space, is likely to house many microorganisms that could not only harm the health of the occupants but also degrade the documentary heritage and wood material of this building.

\subsection{Sampling Procedure}

All samples were taken from the CL-UYI, in the air, on solid surfaces and on books. For each sample, two culture media were used: sabouraud dextrose agar (SDA) supplemented with chloramphenicol $(0.5 \mathrm{~g} / \mathrm{l})$ to isolate fungi and Muller Hinton agar supplemented with nystatin $(0.5 \mathrm{~g} / \mathrm{l})$ to isolate bacteria. Samples were collected according to the methods described by the Higher Council of Public Hygiene of France [9], and adapted to our work. In order to highlight the maximum number of species and ensure the reliability of the results, we sampled them simultaneously. All Petri dishes were labelled according to the location, time and type of sample. And for each of the sampling series, a control was used to ensure that all the microorganisms came from the collection site.

\subsection{Bioaerosol Sampling}

Bioaerosols were taken on study tables and bookcases of the ground floor, the basement, levels 1 and 2 by passive air sampling technique: the settle plate method using $9 \mathrm{~cm}$ diameter Petri dishes. The sampling height (which approximated to human breathing zone) was $1 \mathrm{~m}$ above the floor level. The sampling times were set at 30,60, 90 min. to allow not only the spores in the air to decant freely and to settle on the agar medium contained in petri dish, but also to obtain the appropriate surface density for counting and to determine the load with respect to time of exposure [10]. Moreover, samples were collected twice a day at 
7:30 am in the morning in the absence of people and 14:30 pm in the presence of students to assess the influence of human presence on the microbial load. During the whole study, parameters such as temperature and humidity were also measured.

After exposure, the samples were taken to the CHUY bacteriology laboratory and incubated at $37^{\circ} \mathrm{C}$ for $24 \mathrm{~h}$ for bacteria and at $25^{\circ} \mathrm{C}$ for $2-7$ days for fungi. Once colony forming units (CFU) were enumerated, microbial load $\left(\mathrm{CFU} / \mathrm{m}^{3}\right)$ was determined, taking into account the following Equation (1) described by Omeliansky [11] [12].

$$
N=5 a \times 10^{4}(b t)^{-1}
$$

where $\mathrm{N}=$ microbial $\mathrm{CFU} / \mathrm{m}^{3}$ of indoor air; $\mathrm{a}=$ number of colonies in Petri dish; $\mathrm{b}=$ dish surface $\left(\mathrm{cm}^{2}\right) ; \mathrm{t}=$ exposure time $(\mathrm{min})$.

\subsection{Solid Surface Sampling}

The swabbing method was used to collect microorganisms from study tables, bookcases and surfaces. Dust was collected in a square of $25 \mathrm{~cm}^{2}$ using cotton swabs. Subsequently, these swabs were carried to the laboratory where one swab was used for enumeration and the other for identification after enrichment of microorganisms in the BCC for 24 hours. Once colony forming units (CFU) were enumerated after serial dilutions, microbial load $\left(\mathrm{CFU} / \mathrm{m}^{2}\right)$ was determined, using the following Equation (2) [13].

$$
C=N \cdot V \cdot D \cdot(S)^{-1}
$$

where $\mathrm{C}=$ microbial $\mathrm{CFU} / \mathrm{cm}^{2} ; \mathrm{N}=$ number of colonies in petri dish; $\mathrm{V}=$ volume of the stock solution; $\mathrm{D}=$ inverse of the dilution factor; $\mathrm{S}=$ total area sampled

The isolation of microorganisms on the books was carried out by swabbing and dust tapping method. Using a moistened sterile swab, we rubbed lightly on books with foxing and mold spots.

After incubation, the various colonies observed on the plates were each introduced on new media for purification and well isolated colonies. Each pure isolate was stored at $4^{\circ} \mathrm{C}$ in creotubes containing $10 \%$ glycerinated $\mathrm{BCC}$ for identification.

\subsection{Microbial Identification}

Once the isolation was achieved, the isolates obtained were identified. Bacterial colonies were initially characterized by morphology and microscopic appearance, and identified further by biochemical tests according to the protocol of Joffin and Leyral [14] and Rajesh and Rattan [15]. A wet mount of each fungal colony was prepared by using Lacto phenol cotton-blue solution and examined microscopically. Identification of fungi was based mainly on growth colonial appearance, microscopic examination of the spore and hyphal characteristics of the stained preparations and was orientated by the identification keys of biofor- 
ma [16] and Dufresne [17].

\section{Results}

The indoor air and solids surfaces microbial loads of central library of the University of Yaoundé I were determined by taking 76 samples. The results of the bacterial and fungal concentration range, arithmetic mean and standard deviation of aerosol present in sampling sites are presented in Tables 1-3 respectively.

Table 1. Number of bacterial $\mathrm{CFU} / \mathrm{m}^{3}$ air at different sampling time of day at different time of exposure.

\begin{tabular}{|c|c|c|c|c|c|c|c|c|}
\hline \multirow{4}{*}{ Sampling site } & \multirow{3}{*}{\multicolumn{2}{|c|}{$\begin{array}{c}\text { Environmental } \\
\text { parameters }\end{array}$}} & \multicolumn{6}{|c|}{ Sampling time } \\
\hline & & & \multicolumn{2}{|c|}{$7: 30$ a.m. } & \multirow[b]{2}{*}{$90 \mathrm{~min}$} & \multirow[b]{2}{*}{$30 \mathrm{~min}$} & \multicolumn{2}{|c|}{$2: 30$ p.m. } \\
\hline & & & $30 \mathrm{~min}$ & $60 \mathrm{~min}$ & & & $60 \mathrm{~min}$ & $90 \mathrm{~min}$ \\
\hline & $\begin{array}{c}\text { Temperature } \\
\left({ }^{\circ} \mathrm{C}\right)\end{array}$ & $\begin{array}{c}\text { Humidity } \\
(\%)\end{array}$ & & & $\mathrm{CFU} / \mathrm{m}$ & ${ }^{3}$ of air & & \\
\hline SR basement & 28.9 & 48.1 & 1328 & 1660 & 1900 & 1535 & 1882 & 2035 \\
\hline SR ground floor & 28 & 45.7 & 1162 & 1535 & 1657 & 1342 & 1420 & 1734 \\
\hline SR level 1 & 28 & 38.8 & 913 & 1245 & 1268 & 1121 & 1326 & 1394 \\
\hline SR level 2 & 28 & 38.2 & 996 & 1307 & 1359 & 956 & 1198 & 1279 \\
\hline $\begin{array}{l}\text { Archive area } \\
\text { (basement) }\end{array}$ & 28.9 & 48 & 1277 & 1291 & 1305 & 1319 & 1438 & 1502 \\
\hline
\end{tabular}

Legend: SR = Study Room.

Table 2. Number of fungi $\mathrm{CFU} / \mathrm{m}^{3}$ air at different sampling time of day at different time of exposure.

\begin{tabular}{|c|c|c|c|c|c|c|c|c|}
\hline \multirow{4}{*}{ Sampling site } & \multirow{3}{*}{\multicolumn{2}{|c|}{$\begin{array}{c}\text { Environmental } \\
\text { parameters }\end{array}$}} & \multicolumn{6}{|c|}{ Sampling time } \\
\hline & & & & :30 a.n & & \multicolumn{3}{|c|}{$2: 30$ p.m. } \\
\hline & & & \multicolumn{6}{|c|}{$30 \mathrm{~min} 60 \mathrm{~min} 90 \mathrm{~min} 30 \mathrm{~min} 60 \mathrm{~min} 90 \mathrm{~min}$} \\
\hline & $\begin{array}{c}\text { Temperatures } \\
\left({ }^{\circ} \mathrm{C}\right)\end{array}$ & $\begin{array}{c}\text { Humidity } \\
(\%)\end{array}$ & \multicolumn{6}{|c|}{$\mathrm{CFU} / \mathrm{m}^{3}$ of air } \\
\hline 28.9 SR basement & & 48.1 & 1452 & 1805 & 1964 & 2117 & 2283 & 2324 \\
\hline 28 SR ground floor & & 45.7 & 1245 & 1494 & 1522 & 2034 & 2220 & 2283 \\
\hline 28 SR level 1 & & 38.8 & 1037 & 1120 & 1314 & 830 & 934 & 1051 \\
\hline 28 SR level 2 & & 38.2 & 954 & 1079 & 1231 & 747 & 996 & 1010 \\
\hline $\begin{array}{l}\text { 28.9 Archive area } \\
\text { (basement) }\end{array}$ & & 48 & 1079 & 1183 & 1300 & 1162 & 1598 & 1923 \\
\hline
\end{tabular}

Legend: SR = Study Room

Table 3. The range of microbe's distribution in Yaoundé I University library.

\begin{tabular}{cccccc}
\hline & $\mathrm{N}$ & Minimum & Maximum & Mean & Std. Deviation \\
\cline { 2 - 5 } Bateria CFU/m & & & & & \\
& 30 & 913.00 & 2035.00 & 1389.4667 & 267.29871 \\
Fungi CFU/m $\mathrm{m}^{3}$ & 30 & 747.00 & 2324.00 & 1443.0333 & 489.96076 \\
Valid N (listwise) & 30 & & & & \\
\hline
\end{tabular}


The result obtained showed that there were more suspensions of bioaerosols in the indoor air at afternoon which correlates to the period when persons were found at the sampling sites. Highest $\mathrm{CFU} / \mathrm{m}^{3}$ for both bacterial and fungal were obtained in more confined basement. The highest bacterial CFU $/ \mathrm{m}^{3}$ air was recorded at 2:30 p.m. in basement after $90 \mathrm{~min}$ exposure, which is $2035 \mathrm{CFU} / \mathrm{m}^{3}$, while the lowest bacterial $\mathrm{CFU} / \mathrm{m}^{3}$ air were recorded at 7:30 a.m. in study room (SR) level 1 at $30 \mathrm{~min}$ exposure (Table 1 and Table 3 ). Highest fungal CFU/m ${ }^{3}$ for air samples was recorded at 2:30 p.m. in basement during the 90 min exposure, which is $2324 \mathrm{CFU} / \mathrm{m}^{3}$, while the lowest fungal $\mathrm{CFU} / \mathrm{m}^{3}$ for air samples was recorded at 2:30 p.m.in study room level 2 during the 30 min exposure (Table 2 and Table 3 ). Environmental parameters were approximately $28^{\circ} \mathrm{C}$ for temperature and $57 \%$ for humidity in the entire library.

Table 4 and Table 5 represents the results obtained for surface bacterial and fungal loads $\left(\mathrm{UFC} / \mathrm{cm}^{2}\right)$, arithmetic mean and standard deviation respectively. The highest bacterial and fungal $\mathrm{CFU} / \mathrm{cm}^{2}$ surfaces was recorded on study table of basement which was 340 and $500 \mathrm{CFU} / \mathrm{cm}^{2}$ respectively, while the lowest bacterial and fungal $\mathrm{CFU} / \mathrm{cm}^{2}$ surface was recorded on study table of level 2 which was $60 \mathrm{CFU} / \mathrm{cm}^{2}$ and $40 \mathrm{CFU} / \mathrm{cm}^{2}$ respectively (Table 4 and Table 5).

Results about identification are shown on Table 6. It present the repartition of different bacterial and fungal genera identified in different sampling sites. Bacillus genus and fungi like Aspergillus spp, Penicillium spp and Mucor spp were present in all the sampled sites.

Table 4. Number of bacteria and fungi CFU/ $\mathrm{cm}^{2}$ surface at different sampling sites.

\begin{tabular}{cccc}
\hline & Surfaces sampling & Bacterial CFU $/ \mathrm{cm}^{2}$ & Fungal CFU $/ \mathrm{cm}^{2}$ \\
\hline Study table & Basement & 340 & 500 \\
& Ground floor & 220 & 340 \\
Level 1 & 140 & 140 \\
Wardrobe & Level 2 & 80 & 100 \\
& Basement & 300 & 220 \\
& Ground floor & 140 & 180 \\
Level 1 & 60 & 60 \\
& Level 2 & 60 & 40 \\
\hline
\end{tabular}

Table 5. The range of microbe's distribution in Yaoundé I University library.

\begin{tabular}{cccccc}
\hline $\mathrm{N}$ & & Minimum & Maximum & Mean & Std. Deviation \\
\hline Bacteria CFU/cm & 8 & 60.00 & 340.00 & 167.5000 & 108.46329 \\
fungi CFU $/ \mathrm{cm}^{2}$ & 8 & 40.00 & 500.00 & 197.5000 & 155.44866 \\
Valid N (listwise) & 8 & & & &
\end{tabular}


Table 6. Type of microorganisms isolated from each site of Yaoundé I University library.

\begin{tabular}{|c|c|c|c|}
\hline Microorganisms & Air & surfaces & books \\
\hline \multicolumn{4}{|l|}{ Bacteria } \\
\hline Bacillus spp, & + & + & + \\
\hline Rhodococcus spp, & + & + & - \\
\hline Staphylococcus spp & + & + & + \\
\hline Micrococcus spp & + & + & - \\
\hline Pseudomonas spp & + & + & - \\
\hline Enterobacter spp & + & + & - \\
\hline Klebsiella spp & - & + & - \\
\hline Escherichia spp & - & + & - \\
\hline \multicolumn{4}{|l|}{ fungi } \\
\hline Aspergillus spp & + & + & + \\
\hline Cladosporium spp & + & + & + \\
\hline Mucor spp & + & + & + \\
\hline Fusarium spp & + & + & - \\
\hline Trichophyton spp & + & - & - \\
\hline Acremonium spp & + & - & - \\
\hline Aureobasidium spp & + & + & - \\
\hline Curvularia spp & + & + & - \\
\hline Candida spp & + & + & - \\
\hline Chrysonilia spp & + & + & + \\
\hline Rhizopus spp & - & + & + \\
\hline Rhodotorula spp & + & - & + \\
\hline Penicillium spp & + & + & + \\
\hline
\end{tabular}

Legend: + = presence; $-=$ absence.

Figure 1 and Figure 2 shows the frequency of different groups of bacteria and fungi identified in central library of the University of Yaoundé I. A total of 13 genera of fungi and 8 genera of bacteria were isolated from sampled sites. The most frequent fungal genera were Aspergillus spp (24.40\%) and Penicillium spp (17.32\%). For bacteria, the most frequent genera were Bacillus spp (52\%) and Staphylococcus $\operatorname{spp}(23 \%)$. 


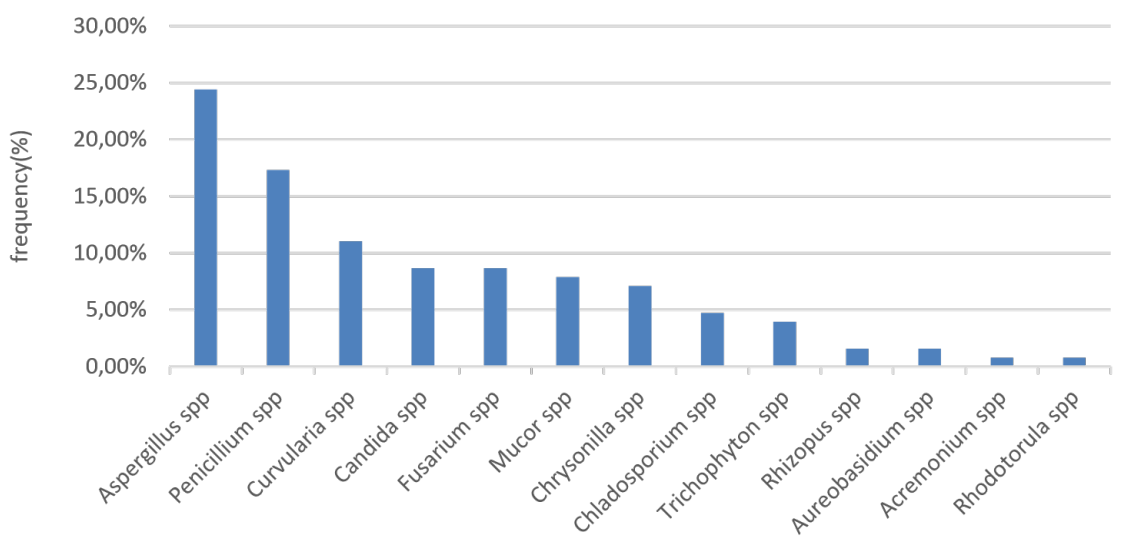

Figure 1. Frequency of fungi identified in the library.

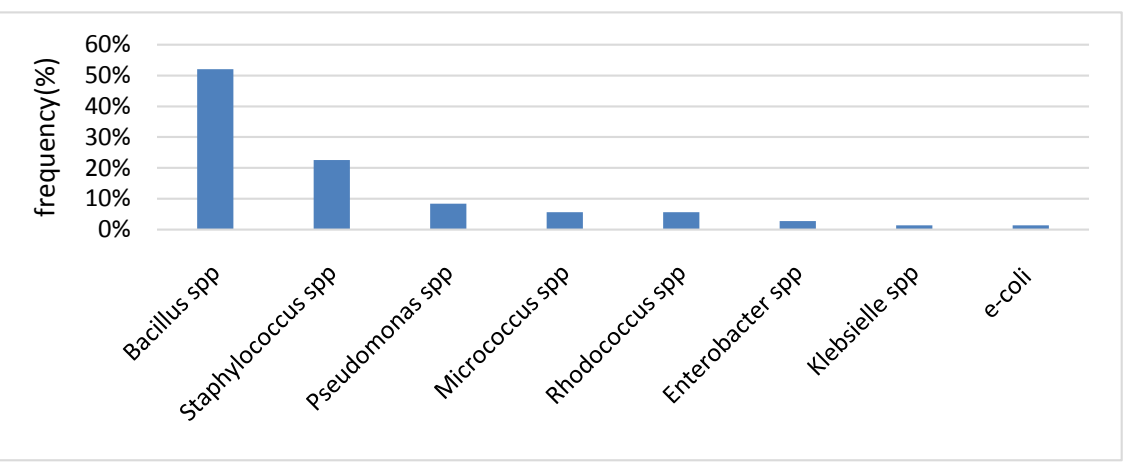

Figure 2. Frequency of bacteria identified in the library.

\section{Discussion}

The inner part of buildings harbours several microorganisms whose number could reach an alarming concentration when the air exchange between the building and the external environment is reduced. The amount of the microbial content of indoor air and surface of library were students spend much of their time is an important parameter because it has a direct impact on the mental health, physical development and performance of the students. Numerous studies have shown that occurrence of bacteria and moulds in the air of school premises pose a great risk to children [18] [19] [20] [21]. From the present study 96 samples of indoor air, surfaces and books were collected from the Central Library which permitted us to isolate $56 \%$ of fungi and $44 \%$ of bacteria.

The concentrations of bacterial and fungi aerosols in the indoor environment of central library of UYI, ranged between $747-2324 \mathrm{CFU} / \mathrm{m}^{3}$. The highest concentrations of both bacteria $\left(2035 \mathrm{CFU} / \mathrm{m}^{3}\right)$ and fungi $\left(2324 \mathrm{CFU} / \mathrm{m}^{3}\right)$ were observed in the basement where there are less openings and afternoon with the presence of human. Microbial concentration of indoor air of the library is affected by many factors, including human activity, the age of the building, ventilation conditions, outdoor air, season (primarily temperature and humidity) [22].

A quantitative interpretation of the results describing the air quality in the li- 
brary is difficult due to the lack of widely accepted normative and reference values. Universally applicable standards defining an acceptable level of indoor air contamination with microorganisms have not yet been established. The sanitary standards of European Commission for non industrial premises consider less than $50 \mathrm{CFU} / \mathrm{m}^{3}$ as "very low" bacterial load, $50-100 \mathrm{CFU} / \mathrm{m}^{3}$ as "low", $100-$ $500 \mathrm{CFU} / \mathrm{m}^{3}$ as "intermediate", $500-2000 \mathrm{CFU} / \mathrm{m}^{3}$ as "high" and above 2000 $\mathrm{CFU} / \mathrm{m}^{3}$ as "very high" bacterial load and consider less than $25 \mathrm{CFU} / \mathrm{m}^{3}$ as "very low" fungal load, $25-100 \mathrm{CFU} / \mathrm{m}^{3}$ as "low", $100-500 \mathrm{CFU} / \mathrm{m}^{3}$ as "intermediate", $500-2000 \mathrm{CFU} / \mathrm{m}^{3}$ as "high" and above $2000 \mathrm{CFU} / \mathrm{m}^{3}$ as "very high" fungal load [23]. According to this classification, the air CL-UYI was in the range of highly or very highly contaminated with bacteria and fungi.

The highest bacterial and fungal $\mathrm{CFU} / \mathrm{m}^{2}$ surfaces has been recorded on study table of basement which was 340 and $500 \mathrm{CFU} / \mathrm{m}^{2}$ respectively, while the lowest bacterial and fungal $\mathrm{CFU} / \mathrm{m}^{2}$ surface were recorded study table level 2 which was $60 \mathrm{CFU} / \mathrm{m}^{2}$ and $40 \mathrm{CFU} / \mathrm{m}^{2}$ respectively. Microbial concentrations and mycobiota on surfaces may differ from those in the indoor air. Therefore, results obtained from surface sampling cannot directly be associated with the exposure to airborne microbes [24]. Surface sampling is, however, one way to determine whether there is a problem and if so, to locate the source of the bio-contamination. In fact, surface sampling is recommended as a supplement to air sampling as a way of detecting fungi in indoor environments [25].

21 groups of microorganisms were identified in the library premise's among which were 8 bacteria (Bacillus spp, Rhodococcus spp, Staphylococcus spp, Micrococcus spp, Pseudomonas spp, Enterobacter spp, Klebsiella spp and Escherichia spp), 2 yeasts (Candida spp and Rhodotorula spp) and 11 molds (Aspergillus spp, Penicillium spp, Curvularia spp, Mucor spp, Cladosporium spp, Fusarium spp, Trichophyton spp, Acremonium spp Aureobasidium spp, Rhizopus spp and Chrysonilia spp). These genera of bacteria and fungi have been shown to be amongst the most common bacterial and fungal genera often isolated from indoor environments. Mandal and Brandl in a review article present those microorganisms as commonly found in habitats [26]. The most frequent fungal genera were aspergillus spp (24.40\%) and penicillium spp (17.32\%). Aspergilus fumigatus is widely distributed in the environment and airborne asexual conidia serves as the main mode of transport for pulmonary lung infection [27] [28] [29]. For bacteria, the most frequent genera were bacillus spp (52\%) and staphylococcus spp (23\%). Staphylococcus is found in all individuals and usually expelled from the respiratory tract through the nose and mouth which may also account for their presence in the environment and can cause bacteremia and gastrointestinal infections [30]. Bacillus species are persistent and resistant in the environment because of the formation of spores. Spores have since been recognized as the hardest known form of life on Earth [31]. The production of spores enables this organism to withstand unfavourable conditions such as low temperatures or heat and may improve the chances of Bacillus to be present in high numbers in the air [32]. The present results agree with those of Kavita and Jyoti 
(2013) who found the same results in school indoor settings [33].

\section{Conclusion}

This research has shown that the sampled sites were laden with microorganisms and most of which are pathogenic to human and can result in mild or adverse health conditions based on individual health status and dose response. Compared with different indoor air biological standards, central library of UYI was heavily contaminated with bacteria and fungi. The high bacterial and fungal load may be due to temperature, humidity and insufficient ventilation. Attention must be given to control those environmental factors which favour the growth and multiplication of microbes in indoor environment.

\section{Acknowledgements}

The authors thank doctor ESSI Marie-José, director of Central library of the University of Yaoundé I for his reception at the library and for the interest she showed for our study.

\section{References}

[1] Nieguitsila, A. (2008) Evaluation of Airborne Contamination in Indoor Environments. PhD Thesis, University of Paris, Paris, 14, 30.

[2] Rocchi, S. (2014) Relationship between Microbiological Profiles of the Indoor Environment and Infectious and Allergic Respiratory Diseases. Human Medicine and Pathology. University of Franche Comte, Besançon.

[3] Chahrazed, B. (2010) Detection of Pollution in the Air Inside Buildings. PhD Thesis, Abou Bekr Belkaid University of Tlemcen, Tlemcen, 53-75.

[4] WHO (2009) Guidelines for Indoor Air Quality, Dampness and Mould Publications. WHO Regional Office for Europe.

http://www.euro.who.int/data/assets/pdf_file/0017/43325/E92645.pdf

[5] WHO (2016) Indoor Air Pollution Habitats and Health. Checklist N²92 Site Consulted Online. http://www.int/entity/mediacenter(fctsheets/fs292/fr/index.htlm

[6] Strang, T. and Kigawa, R. (2009) Pest Control of Cultural Property. Canadian Conservation Institute, Technical Bulletin No. 29.

[7] Kamdem, P.C. (2011) Where Will the Cameroonian Libraries Be in Ten Years? Bulletin of the Libraries of France, 6, 48-52.

[8] Wood, L. (1988) Prevention and Treatment of Molds in Library Collections, Especially in Tropical Climates: A RAMP Study/Prepared by Mary Wood Lee [for the] General Information Program and UNISIST. Unesco, Paris, 56 p.

[9] Caillaud, D., Annesi, M., Bennedjai Bex, U., De Blay, F., Charpin, D., Dalphin, S.C., Fabre, C., Garans, M., Joyeux, M., Meunier, D., Mouilleseaux, A., Nolard, N., Ravault, N., Roboux, G. and Robine Roquebert, M.F. (2006) Fungal Contamination in Internal Environment, Diagnostic and Effect on Repiratory Health, Conduct to Keep. High Concil of Public Health of France, 10-18.

[10] Fekadu, H.S. and Melaku, M.A. (2014) Microbiological Quality of Indoor Air in University Libraries. Asian Pacific Journal of Tropical Biomedicine, 4, 312-317. https://doi.org/10.12980/APJTB.4.2014C807 
[11] Borrego, S., Guiamet, P., de Saravia, S.G., Batistini, P., Garcia, M., Lavin, P., et al. (2010) The Quality of Air at Archives and the Biodeterioration of Photographs. International Biodeterioration and Biodegradation, 64, 139-145. https://doi.org/10.1016/j.ibiod.2009.12.005

[12] Gutarowska, B. (2010) Metabolic Activity of Moulds as a Factor of Building Materials Biodegradation. Polish Journal of Microbiology, 59, 119-124.

[13] Teagasc (2008) Standard Operating Procedure Microbiological Examination for Checks of Cleaning and Disinfection in Meat Establishments. Agriculture and Food Development Authority, 1-8.

[14] Leyral, G. and Joffin, J.N. (1998) Technical Microbiology: 2, Technical Documentation. 2nd Edition, CRDP d'Aquitaine, Bordeaux, $304 \mathrm{p}$.

[15] Rajash, B. and Rattan, L.I. (2008) Essential of Medical Microbiology. 4th Edition, Jayppe Brothers Medical Publishers, New Delhi, 415-439.

[16] BIOFORMA (2002) Molds of Medical Interest. Parasitology and Mycology Laboratory Anger, $160 \mathrm{p}$.

[17] Dufresne, P. (2014) Identification of Molds of Medical Interest. Public Health Laboratory Quebec, $59 \mathrm{p}$.

[18] Jędrzejewska-Ścibak, S.J. (2002) Publishing House of Warsaw. University of Technology, Warsaw.

[19] Quah, B.S., Wan-Pauzi, I., Ariffin, N. and Mazidah, A.R. (2005) Prevalence of Asthma, Eczema and Allergic Rhinitis: Two Surveys 6 Years Apart in Kota Bharu, Malaysia. Respirology, 10, 244-249. https://doi.org/10.1111/j.1440-1843.2005.00645.x

[20] Richards, W. (1986) Allergy, Asthma, and School Problems. Journal of School Health, 56, 151-152. https://doi.org/10.1111/j.1746-1561.1986.tb05725.x

[21] Halide, A., Ahmet, A., Muserref, T.O. and Mevlut, T. (2005) Monitoring of Fungi and Bacteria in the Indoor Air of Primary Schools in Edirne City, Turkey. Indoor and Built Environment, 14, 411-425.

[22] Thorstensen, E.C., Hansen, J., Pejtersen, G.H., Clausen and Fanger, P.O. (1990) Air Pollution Sources and Indoor Air Quality in Schools. Proceedings of the 5 th International Conference on Air Quality and Climate, Toronto, 29 July-3August 1990, 531-536.

[23] Commission of the European Communities (1993) Indoor Air Quality and Its Impact on Man. Biological Particles in Indoor Environments, Report No. 12, Commission of the European Communities, Luxembourg.

[24] Niemeier, R.T., Sivasubramani, S.K., Reponen, T. and Grinshpun, S.A. (2006) Assessment of Fungal Contamination in Moldy Homes: Comparison of Different Methods. Journal of Occupational and Environmental Hygiene, 5, 262-273. https://doi.org/10.1080/15459620600637333

[25] Reenen-Hoekstra, E.S., Samson, R.A., Verhoeff, A.P., Wijnen, J.H. and Brunekreef, B. (1991) Detection and Identification of Molds in Dutch Houses and Nonindustrial Working Environments. Grana, 30, 418-423. https://doi.org/10.1080/00173139109432001

[26] Mandal, J. and Brandl, H. (2011) Bioaerosols in Indoor Environment. The Open Environmental and Biological Monitoring Journal, 4, 83-96.

[27] Recer, G., Browne, M., Horn, E., Hill, K. and Boehler, W. (2001) Ambient Air Levels of Aspergillus fumigatus and Thermophilic Actinomycetes in a Residential Neighborhood near a Yard-Waste Composting Facility. Aerobiologia, 17, 99-108. 
https://doi.org/10.1023/A:1010816114787

[28] Boone, S.A. (2007) Significance of Fomites in the Spread of Respiratory and Enteric Viral Disease. Applied and Environmental Microbiology, 73, 1687-1696. https://doi.org/10.1128/AEM.02051-06

[29] Kalwasinska, A., Burkowska, A. and Wilk, I. (2012) Microbial Air Contamination in Indoor Environment of the University Library. Aerosol and Air Quality Research, 19, 25-29.

[30] Kim, K.Y., Kimb, H.T., Kim, D., Nakajimad, J. and Higuchi, T. (2009) Distribution Characteristics of Airborne Bacteria and Fungi in the Feed Stuff Manufacturing Factories. Journal of Hazardous Material, 169, 1054-1060.

https://doi.org/10.1016/j.jhazmat.2009.04.059

[31] Wayne, L., Nicholson, N., Munakata, G.H., Henry Melosh, J. and Peter, S. (2000) Resistance of Bacillus Endospores to Extreme Terrestrial and Extraterrestrial Environment. Microbiology and Molecular Biology Reviews, 64, 548-572.

[32] Whyte, P., Collins, J.D., McGill, K., Monahan, C. and O’Mahony, H. (2001) Distribution and Prevalence of Airborne Microorganisms in Three Commercial Poultry Processing Plants. Journal of Food Protection, 64, 388-391.

https://doi.org/10.4315/0362-028X-64.3.388

[33] Kavita, N. and Jyoti, G. (2013) Microbial Contamination in a School. International Journal of Current Microbiology and Applied Sciences, 12, 404-4010. 